\title{
Uji Antagonisme Jamur Endofit Tanaman Aren (Arenga pinnata Merr.) terhadap Ganoderma boninense Pat. Penyebab Penyakit Busuk Pangkal Batang Kelapa Sawit
}

\author{
Muhammad Ali*, dan Ira Yesica Samosir \\ Fakultas Pertanian, Universitas Riau \\ Jl. H.R. Soebrantas Km. 12,5 Simpang Baru, Pekanbaru 28293 \\ *Alamat korespondensi: alimuhhusman61@gmail.com
}

\begin{tabular}{lcc}
\hline \multicolumn{2}{c}{ INFO ARTIKEL } & ABSTRACT/ABSTRAK \\
\hline Diterima: & $15-11-2021$ & \\
Direvisi: & $11-01-2022$ & Antagonism of Endophytic Fungi from Sugar Palm (Arenga pinnata Merr.) \\
Dipublikasi: & $23-01-2022$ & against Ganoderma boninense Pat. the Causal Agent of Basal Stem Rot \\
& & Disease of Oil Palm
\end{tabular}

Keywords:

Endophytic, Inhibiton, Isolation, Stem rot disease

Kata Kunci:

Busuk pangkal batang, Daya hambat, Endofit, Isolasi
Ganodema boninense is the causal agent of basal stem rot disease on oil palm plants which can cause economic losses in Riau Province. One of the control methods is the use of endophytic fungi as biological control agents. The aims of this study was to evaluate antagonism of endophytic fungi isolated from sugar palm plants against $G$. boninense in vitro. This research was conducted at the Plant Disease Laboratory, Faculty of Agriculture, Riau University from July to November 2020. The research was carried out by exploration, experiment and observation. The isolation from leaves, bark and root of sugar palm obtained 25 isolates of endophytic fungi. Among the isolates, there were seven isolates inhibited the growth of $G$. boninense by $50.17 \%-67.05 \%$. The endophytic fungi ( $\mathrm{E}_{2}, \mathrm{E}_{17}, \mathrm{E}_{18}$ isolates) caused lysis of the pathogen hypae. There were sticking (showed by E3, E15, E25 isolates) and entrapment (showed by $\mathrm{E}_{16}$ isolate) of endophytic hypae to the pathogen hypae. Results of identification showed that three isolates belonging to the genus Trichoderma (E2, E16, E18), one isolate of the genus Papulaspora(E15), one isolate of the genus Aspergillus (E3), one isolate of the genus Syncephalastrum (E17) and one isolate of the genus Mucor (E25).

Ganodema boninense merupakan penyebab penyakit busuk pangkal batang pada tanaman kelapa sawit yang dapat menimbulkan kerugian secara ekonomi di Provinsi Riau. Salah satu teknik pengendalian yang dapat dilakukan adalah penggunaan jamur endofit sebagai agens hayati. Penelitian ini bertujuan untuk menguji kemampuan antagonisme jamur endofit dari tanaman aren terhadap $G$. boninense penyebab penyakit busuk pangkal batang kelapa sawit. Penelitian ini dilaksanakan di Laboratorium Penyakit Tanaman, Fakultas Pertanian, Universitas Riau pada bulan Juli hingga November 2020. Penelitian dilaksanakan dengan metode eksplorasi, eksperimen dan observasi. Isolasi dari daun, batang dan akar tanaman aren menemukan 25 isolat jamuer endofit. Di antara isolat jamur endofit terdapat tujuh isolat yang menghambat pertumbuhan $G$. boninense sebesar 50,17\% 67,05\% yaitu 67,05\% (E2), 66,11\% (E16), 61,43\% (E18), 52,22\% (E15), 51,23\% (E3), 50,72\% (E17) dan 50,17\% (E25). Pada pengamatan mikroskopis , jamur endofit (isolat E2, E17, E18) menyebabkan hifa $G$. boninense menjadi lisis. Terdapat pula penempelan (isolat $E_{3}, E_{15}, E_{25}$ ) dan penjeratan (isolat E16) hifa G. boninense oleh hifa jamur endofit. Hasil identifikasi menunjukkan bahwa 
tiga isolat termasuk ke dalam genus Trichoderma (E2, $\left.\mathrm{E}_{16}, \mathrm{E}_{18}\right)$, satu isolat

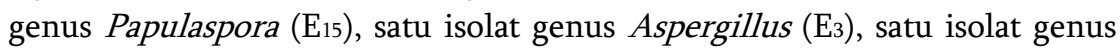
Syncephalastrum (E17) dan satu isolat genus Mucor (E25).

\section{PENDAHULUAN}

Tanaman kelapa sawit (Elaeis guineensis) merupakan salah satu tanaman perkebunan yang menjadi sektor andalan ekonomi di Provinsi Riau. Hal ini terbukti bahwa Provinsi Riau memiliki luas perkebunan ke-5 terbesar di Indonesia. Berdasarkan data dari Direktorat Jendral Perkebunan (2021), luas lahan kelapa sawit terus menerus meningkat setiap tahunnya, dengan jumlah pertumbuhan luas lahan (2018-2019) sebesar 1,28\%, namun peningkatan luasan areal budidaya tanaman kelapa sawit di Riau tidak selalu berbanding lurus dengan peningkatan produksinya.

Tahun 2018-2019 luas areal pertanaman Kalimantan Selatan mengalami penurunan sebesar $13,12 \%$, namun peningkatan produksi kelapa sawit di Riau lebih rendah dibandingkan di Kalimantan Selatan yaitu berturut-turut sebesar 11,97\% dan 13,74\% (Ditjenbun, 2021). Hal ini disebabkan oleh teknis budidaya yang kurang optimal, kondisi lingkungan dan kesuburan tanah yang kurang baik, serta infeksi patogen. Salah satu patogen yang dapat menyerang kelapa sawit adalah Ganodema boninense.

G. boninense merupakan penyebab penyakit busuk pangkal batang (BPB) pada kelapa sawit yang menjadi kendala dalam peningkatan produksi. Berdasarkan data dari Dinas Perkebunan Provinsi Riau (2014), G. boninense telah menginfeksi perkebunan kelapa sawit rakyat di Riau seluas 533,8 ha. Penyakit BPB telah menyebabkan kematian kelapa sawit hingga $80 \%$ (Susanto, 2002). Pengendalian penyakit karena $G$. boninense yang umum dilakukan adalah dengan menggunakan metode kultur teknis, aplikasi fungisida sintetik berbahan carboxin. Namun demikian, pengendalian ini masih kurang efektif karena $G$. boninense dapat bertahan lama di dalam tanah dalam bentuk klamidospora. Pengendalian lainnya yang dapat dilakukan adalah menggunakan jamur endofit.

Pemanfaatan jamur endofit diharapkan menjadi upaya pengendalian yang efektif karena jamur ini berasal dari jaringan tanaman dan dapat lebih mudah beradaptasi pada tanaman sehingga dapat mengendalikan jamur $G$. boninense yang juga berada di dalam jaringan tanaman. Hasil penelitian
Yusriani (2019) menunjukkan bahwa isolat endofit dari tanaman sagu memiliki daya antagonisitik tinggi terhadap $G$. boninense sebesar 72,26\%. Penelitian tentang pemanfaatan jamur-jamur endofit dari tanaman yang masih termasuk ke dalam Famili Palmae lainnya seperti tanaman aren belum pernah dilaporkan.

Tanaman aren merupakan tanaman yang umumnya dapat tumbuh secara alami pada kondisi tanah yang marginal dan belum banyak terserang hama dan penyakit. Ketahanan yang dimiliki oleh tanaman aren tersebut perlu diteliti lebih lanjut, apakah tanaman tersebut memiliki jamur endofit yang dapat dimanfaatkan sebagai agens hayati untuk meningkatkan ketahanan tanaman dan mengendalikan penyakit tanaman. Penelitian ini bertujuan untuk menyeleksi dan menguji daya antagonis jamur-jamur endofit dari tanaman aren serta mendapatkan jamur endofit yang berdaya antagonis tinggi sebagai agens hayati terhadap $G$. boninense.

\section{BAHAN DAN METODE}

Penelitian ini dilaksanakan di Laboratorium Penyakit Tumbuhan Fakultas Pertanian, Universitas Riau, Kampus Bina Wudya km 12,5 Kelurahan Simpang Baru Kecamatan Tampan Pekanbaru. Penelitian dilakukan dari bulan Juli 2020 hingga November 2020. Pengambilan sampel daun, batang dan akar tanaman aren dilakukan di daerah Kelurahan Palas, Kecamatan Rumbai, Kota Pekanbaru.

\section{Isolasi Jamur Endofit Tanaman Aren}

Jamur endofit diisolasi dari 5 tanaman sampel pada jaringan daun (diambil dari bagian tengah helaian daun yang berada di posisi tengah dari tajuk tanaman sepanjang $15 \mathrm{~cm}$ ), batang (diambil pada ketinggian $175 \mathrm{~cm}$ dari pangkal batang sepanjang 10 cm yaitu bagian kulit dan kambium batang) dan akar (diambil pada kedalaman $10 \mathrm{~cm}$ dari permukaan tanah dengan panjang $10 \mathrm{~cm}$ dari pangkal batang dengan akar berdiameter $0,7 \mathrm{~cm}-1 \mathrm{~cm}$ ) tanaman aren. Isolasi jamur endofit dilakukan dengan menggunakan metode menurut Wilia dkk. (2012) yang telah dimodifikasi. 
Jaringan akar, batang dan dau dicuci menggunakan air mengalir kemudian Jaringan dipotong dengan ukuran $1 \mathrm{~cm} \times 1 \mathrm{~cm}$, kemudian disterilkan di dalam alkohol 70\% selama 1 menit. Potongan jaringan tanaman aren di rendam kembali ke dalam larutan $0.5 \% \mathrm{NaOCl}$ selama 1 menit lalu dibersihkan dengan merendamkannya di dalam aquades steril diulang sebanyak 2 kali dan dikeringkan. Sampel jaringan diletakkan di atas media PDA steril dalam cawan petri kemudian di inkubasi selama 7 hari pada suhu kamar. Jamur yang tumbuh dimurnikan pada media PDA dan diidentifikasi.

\section{Uji Daya Antagonistik Jamur Endofit terhadap Ganoderma boninense}

Uji daya antagonistik jamur endofit dari tanaman aren dilakukan dengan menggunakan metode biakan ganda (dual culture). Masing-masing potongan isolat jamur endofit dan jamur patogen berdiameter $5 \mathrm{~mm}$ diletakkan di bagian pinggir cawan petri dengan jarak berlawanan $3 \mathrm{~cm}$. Perhitungan daya antagonistik diamati pada hari ke7 setelah inkubasi dan dihitung dengan rumus menurut Fokema (1973) dalam (Skidmore, 1976) sebagai berikut:

Keterangan:

$$
\mathrm{P}=\frac{\mathrm{r}_{1}-\mathrm{r}_{2}}{\mathrm{r}_{1}} \mathrm{X} 100 \%
$$

$\mathrm{P}=$ Persentase daya hambat (\%)

$\mathrm{r}_{1}=$ Jari-jari koloni patogen yang menjauhi jamur antagonis (mm)

$\mathrm{r}_{2}$ = Jari-jari koloni patogen yang mendekati jamur antagonis (mm)

\section{Uji Pertumbuhan Isolat Jamur Endofit Tanaman Aren} yang Berdaya Antagonistik Tinggi

Jamur endofit berdaya antagonistik $>50 \%$ ditumbuhkan kembali pada media PDA steril dalam cawan petri, kemudian diinkubasi sampai salah satu isolat memenuhi cawan petri (2 hari setelah inkubasi). Diameter koloni dihitung dengan rumus:

$$
\mathrm{D}=\frac{\mathrm{d}_{1}+\mathrm{d}_{2}}{2}
$$

Keterangan:

$\mathrm{D}=$ Diameter jamur

$\mathrm{d}_{1}=$ Diameter horizontal jamur endofit tanaman aren

$\mathrm{d}_{2}=$ Diameter vertikal jamur endofit tanaman aren
Uji Hiperparasitik Jamur Endofit Tanaman Aren terhadap Ganoderma boninense

Jamur endofit berdaya antagonistik $>50 \%$ diuji dengan menggunakan teknik slide culture yaitu mula-mula kaca objek diletakkan pada bagian tengah cawan petri steril, kemudian media PDA steril dituangkan ke dalam cawan petri tersebut dengan ketebalan $\pm 0,01 \mathrm{~mm}$ di atas kaca objek. Potongan Isolat jamur endofit dan isolat jamur $G$. boninese berdiameter $5 \mathrm{~mm}$ dan diletakkan pada bagian pinggir dari kaca objek yang berlawanan dengan potongan jamur endofit dengan jarak $3 \mathrm{~cm}$. isolat kemudian diinkubasi sampai kedua isolat saling menyentuh lalu dipotong dan diamati dengan menggunakan mikroskop.

\section{Identifikasi Isolat Jamur Endofit Tanaman Aren}

Pengamatan morfologi jamur dilakukan terhadap koloni jamur endofit tanaman aren yang ditumbuhkan pada medium PDA yang berumur 3-7 hari setelah inkubasi. Identifikasi yang dilakukan yaitu berdasarkan buku Barnett dan Hunter (1998) dan Watanabe (2002) dengan membuat preparat.

\section{Analisis data}

Data-data yang diperoleh dari hasil pengamatan meliputi hasil isolasi tipe interaksi hiperparasitik jamur endofit tanaman aren terhadap $G$. boninense disajikan dalam bentuk tabel dan gambar. Data dari hasil pengamatan daya hambat jamur endofit tanaman aren serta pengukuran diameter dan kecepatan pertumbuhan jamur endofit tanaman aren dianalisis secara sidik ragam dengan menggunakan aplikasi SPSS (Statistical Product and Service Solutions). Apabila terdapat perbedaan yang nyata antar perlakuan, dilanjutkan dengan uji Duncan's New Multiple Range (DNMRT) pada taraf $5 \%$.

\section{HASIL DAN PEMBAHASAN}

\section{Hasil Isolasi Jamur Endofit dari Tanaman Aren}

Hasil isolasi jamur endofit dari tanaman aren diperoleh 25 isolat jamur yang terdiri dari 10 isolat dari akar, 11 isolat dari batang dan 4 isolat dari daun dan memiliki karakteristik makroskopis yang berbeda. Isolat jamur endofit yang diperoleh dari tanaman aren cukup banyak. Hal ini diduga karena tanaman aren yang menjadi inang jamur endofit ini merupakan tanaman yang tumbuh dan dibudidayakan secara alami sehingga tidak menggunakan pestisida sintetis dalam teknis 
budidayanya. Oleh sebab itu, kondisi lahan dan lingkungan masih asli mendukung tumbuh dan berkembangnya jamur endofit yang relatif banyak jumlahnya di dalam jaringan tubuhnya. Beragamnya isolat jamur endofit yang diperoleh dari tanaman yang tumbuh secara alami diduga disebabkan oleh kemampuan tanaman inang menyediakan nutrisi dan kelangsungan hidup jamur endofit. Isolat yang diperoleh dari batang tanaman aren lebih banyak yaitu 11 isolat dibandingkan dengan organ akar (10 isolat) dan daun (4 isolat). Hal ini diduga karena di dalam jaringan batang tanaman aren mengandung karbohidrat yang tinggi berupa serat-serat yang banyak mengandung selulosa dan miselosa sebagai nutrisi untuk pertumbuhan jamur. Wulandari dkk. (2012) menyatakan bahwa karbohidrat merupakan sumber nutrisi dan energi bagi mikroorganisme.

\section{Daya Hambat Antagonis Jamur Endofit Tanaman Aren terhadap G. boninense secara In Vitro}

Dua puluh tiga isolat jamur endofit tanaman aren secara nyata dapat menghambat pertumbuhan G. boninense setelah dianalisis ragam dan diuji lanjut dengan uji lanjut DNMRT pada taraf $5 \%$. Setiap jamur endofit memiliki daya hambat yang berbeda-beda. Menurut Pelczar dan Chan (1988), perbedaan kemampuan daya antagonis jamur ditentukan oleh aktivitasnya dalam mengendalikan patogen yaitu kompetisi terhadap tempat tumbuh dan nutrisi, antibiosis serta mikoparasitisme. Hasil uji daya hambat jamur endofit tanaman aren terhadap $G$. boninense mendapatkan tujuh isolat berdaya atagonistik $>50 \%$ (Tabel 2).

Tabel 2. Daya hambat isolat jamur endofit tanaman aren terhadap pertumbuhan $G$. boninnense

\begin{tabular}{cc}
\hline Isolat & Daya hambat $(\%)$ \\
\hline $\mathrm{E}_{2}$ & $67,05 \mathrm{a}$ \\
$\mathrm{E}_{16}$ & $66,11 \mathrm{ab}$ \\
$\mathrm{E}_{18}$ & $61,43 \mathrm{ab}$ \\
$\mathrm{E}_{15}$ & $52,22 \mathrm{abc}$ \\
$\mathrm{E}_{3}$ & $51,23 \mathrm{abcd}$ \\
\hline
\end{tabular}

Keterangan: Angka-angka yang diikuti oleh huruf kecil yang sama adalah berbeda tidak nyata menurut hasil uji lanjut duncan new multiple range test (DNMRT) pada taraf $5 \%$ setelah di transformasi $\sqrt{\mathrm{k}-\mathrm{y}}$

Isolat jamur endofit tanaman aren yang dapat menghambat pertumbuhan patogen $>50 \%$ berpotensi sebagai agens hayati dalam mengendalikan $G$. boninense. Menurut Otten et al. (2004), jamur yang memiliki daya hambat $>50 \%$ berpotensi digunakan sebagai agens hayati untuk mengendalikan jamur patogen. Mekanisme antagonisme ketujuh isolat jamur endofit tanaman aren yang berdaya antagonistik $>50 \%$ terhadap $G$. boninense dapat dilihat pada Gambar 1.

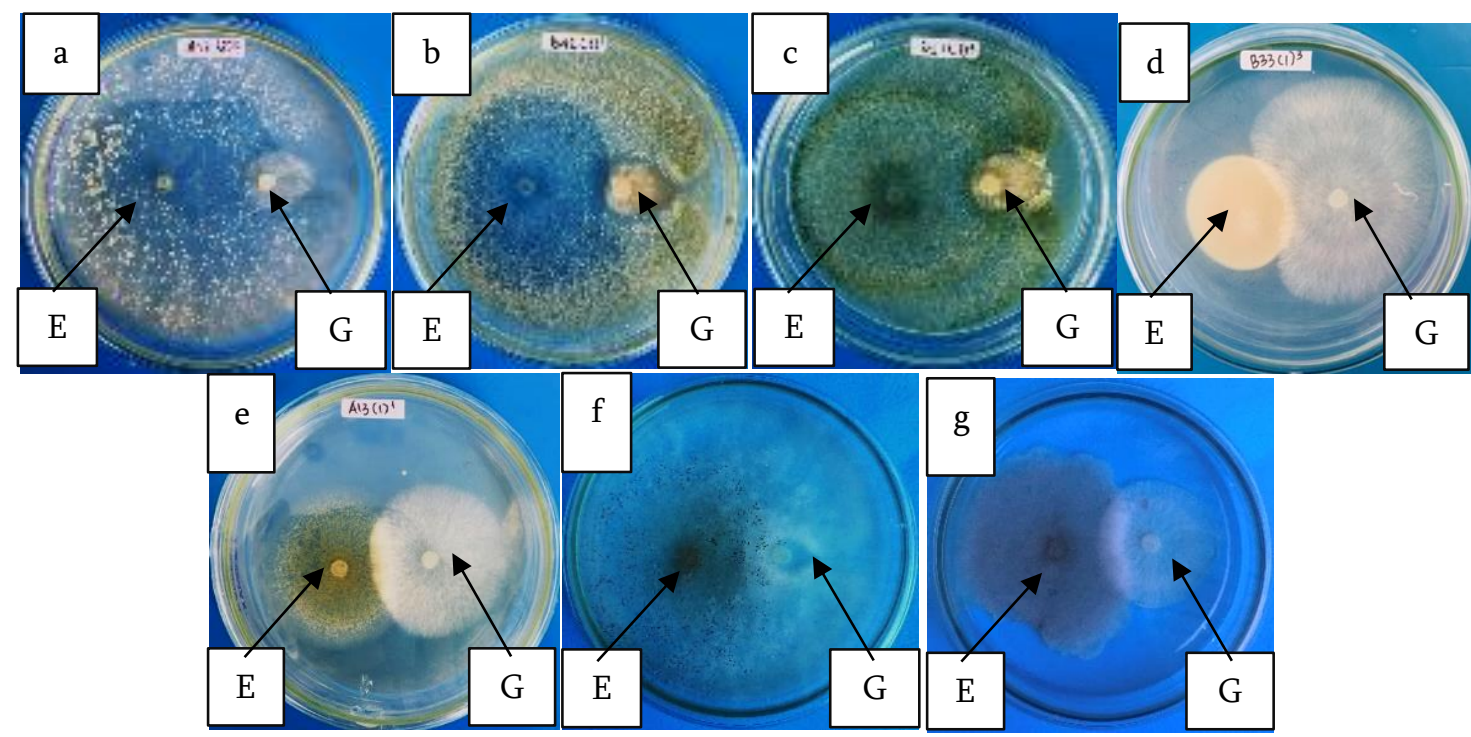

Gambar 1. Penghambatan pertumbuhan G. boninense oleh isolat jamur endofit dari tanaman aren pada medium PDA. a) Isolat $E_{2}$, b) Isolat $\left.E_{16}, c\right)$ Isolat $E_{18}, d$ ) Isolat $\left.E_{15}, e\right)$ Isolat $E_{3}, f$ ) Isolat E17, g) Isolat $\mathrm{E}_{25} \mathrm{G}=\mathrm{G}$. boninense, $\mathrm{E}=$ jamur endofit 
Koloni jamur G. boninense yang berdekatan dengan miselia dari isolat jamur endofit tanaman aren memperlihatkan adanya perubahan warna putih menjadi kuning pada ujung miselium (Gambar 1a, 1b dan 1c). Hal ini diduga bahwa isolat $E_{2}, E_{16}$ dan $E_{18}$ yang termasuk ke dalam genus Trichoderma (Gambar 3a, 3d dan 3f) mengeluarkan metabolit sekunder berupa toksin atau enzim yang dapat meracuni miselia isolat jamur $G$. boninense, sehingga miseliumnya mengalami perubahan warna dan pertumbuhannya menipis. Hal ini didukung oleh pendapat Vinale et al. (2008) yang menyatakan bahwa metabolit sekunder yang dihasilkan oleh Trichoderma sp. dapat mendegradasi dinding sel patogen.

Pada dual culture dengan jamur endofit isolat E15 dan E3, pertumbuhan miselium jamur $G$. boninense mengalami penipisan dan cenderung tumbuh ke arah atas dan tidak ke samping (Gambar 1d dan 1e). Hal ini menunjukkan terjadi kompetisi ruang tumbuh dan nutrisi oleh isolat $\mathrm{E}_{15}$ dan $\mathrm{E}_{3}$ hingga menyebabkan pertumbuhan miselium jamur G. boninense terdesak ke bagian atas dalam media tumbuh. Purwanti \& Hastuti (2009) menyatakan bahwa kompetisi ruang dan nutrisi yang terjadi antara jamur antagonis dengan jamur patogen akan menyebabkan terdesaknya pertumbuhan miselium jamur patogen, sehingga pertumbuhan miseliumnya cenderung ke arah atas dan tidak ke samping.

Pada perlakuan dengan isolat $\mathrm{E}_{17}$ dan $\mathrm{E}_{25}$ miselium jamur endofit tumbuh di atas miselium jamur $G$. boninense (Gambar 1f dan $1 \mathrm{~g}$ ). Hal ini diduga terjadi aktivitas hiperparasitisme antara isolat terhadap jamur G. boninense. Aktivitas hiperparasitisme yang terjadi antara jamur antagonis dengan jamur patogen salah satunya ditandai dengan adanya kemampuan miselium jamur antagonis tumbuh di atas miselium jamur patogen (Krishnamurthy et al., 1999).

\section{Diameter Koloni dan Kecepatan Pertumbuhan Koloni Jamur Endofit dari Tanaman Aren yang Berdaya Antagonistik Tinggi terhadap G. boninense}

Kecepatan pertumbuhan koloni jamur endofit yang diuji berbeda tergantung isolatnya. Isolat $\mathrm{E}_{25}$ memiliki diameter dan kecepatan pertumbuhan yang tertinggi yaitu $90,00 \mathrm{~mm}$ dan $55,88 \mathrm{~mm}$ /hari yang berbeda nyata dengan keenam isolat lainnya (Tabel 3). Pertumbuhan isolat E25 sangat cepat kemungkinan dikarenakan kemampuannya dalam menyerap nutrisi pada media tumbuh sangat tinggi. Djafaruddin (2000) dalam Amaria dkk. (2013) menyatakan bahwa kecepatan pertumbuhan koloni jamur antagonis merupakan salah satu faktor penting dalam menentukan potensinya sebagai agens hayati terhadap jamur patogen. Isolat $\mathrm{E}_{15}$ adalah isolat yang memiliki diameter dan kecepatan pertumbuhan terendah yaitu $20,63 \mathrm{~mm}$ dan $9,75 \mathrm{~mm} /$ hari yang diameter dan kecepatan pertumbuhannya berbeda nyata dengan keenam isolat lainnya.

Tabel 3. Diameter dan kecepatan pertumbuhan isolat jamur endofit yang berdaya antagonistik tinggi (2 hari setelah inkubasi)

\begin{tabular}{lcc}
\hline Isolat & $\begin{array}{c}\text { Diameter } \\
(\mathrm{mm})\end{array}$ & $\begin{array}{c}\text { Kecepatan pertumbuhan } \\
(\mathrm{mm} / \mathrm{hari})\end{array}$ \\
\hline $\mathrm{E}_{25}$ & $90,00 \mathrm{a}$ & $55,88 \mathrm{a}$ \\
$\mathrm{E}_{16}$ & $73,13 \mathrm{~b}$ & $43,88 \mathrm{~b}$ \\
$\mathrm{E}_{2}$ & $72,63 \mathrm{~b}$ & $42,13 \mathrm{bc}$ \\
$\mathrm{E}_{18}$ & $69,38 \mathrm{c}$ & $40,75 \mathrm{c}$ \\
$\mathrm{E}_{17}$ & $65,5 \mathrm{~d}$ & $36,63 \mathrm{~d}$ \\
$\mathrm{E}_{3}$ & $32,75 \mathrm{e}$ & $17,50 \mathrm{e}$ \\
$\mathrm{E}_{15}$ & $20,63 \mathrm{f}$ & $9,75 \mathrm{f}$ \\
\hline
\end{tabular}

Keterangan: Angka-angka yang diikuti oleh huruf kecil yang sama adalah berbeda tidak nyata menurut hasil uji lanjut duncan new multiple range test (DNMRT) pada taraf $5 \%$.

Tipe Interaksi Jamur Endofit Tanaman Aren yang Berdaya Antagonistik >50\% terhadap G. boninense

Berdasarkan pengamatan secara mikroskopis, terdapat perbedaan tipe interaksi antara jamur endofit tanaman aren terhadap jamur patogen $G$. boninense. Isolat-isolat jamur endofit ada yang menyebabkan terjadinya lisis da nada pula yang mengindikasikan adanya interaksi hiperparasitisme yang ditandai dengan adanya penempelan dan penjeratan hifa $G$. boninense (Tabel 4; Gambar 2).

Tabel 4. Interaksi isolat jamur endofit tanaman aren dengan $G$. boninense

\begin{tabular}{ll}
\hline \multicolumn{1}{c}{ Isolat } & \multicolumn{1}{c}{ Tipe hiperparasitik } \\
\hline $\mathrm{E}_{2}, \mathrm{E}_{17}, \mathrm{E}_{18}$ & Lisis \\
$\mathrm{E}_{3}, \mathrm{E}_{15}, \mathrm{E}_{25}$ & Penempelan \\
$\mathrm{E}_{16}$ & Penjeratan \\
\hline
\end{tabular}

Interaksi antara isolat E2, E15, dan $\mathrm{E}_{18}$ dengan G. boninense menunjukkan adanya hifa yang lisis sehingga menyebabkan hifa tampak terputus-putus (Gambar 2a), berwarna bening (kosong) (Gambar 2f) dan terlihat beberapa hifa menjadi hancur (Gambar 2c). Menurut Sari \& Setiwanto (2015), mekanisme lisis ditandai dengan berubahnya warna hifa jamur patogen menjadi bening, kosong, putus-putus hingga 
hancur. Hal ini diduga bahwa isolat $\mathrm{E}_{2}, \mathrm{E}_{17}$, dan $\mathrm{E}_{18}$ mengeluarkan enzim dan toksin yang dapat menghancurkan hifa patogen. Pernyataan ini didukung oleh pendapat Habazar dan Yaherwandi (2006) dalam Alviodinasyari (2015) bahwa jamur
Trichoderma spp. yang berinteraksi dengan jamur patogen dapat menghasilkan enzim seperti $\beta-1$, 3glukanase, kitinase dan selulase yang mampu menghidrolisis dinding sel jamur patogen sehingga hifa tersebut menjadi hancur (lisis).

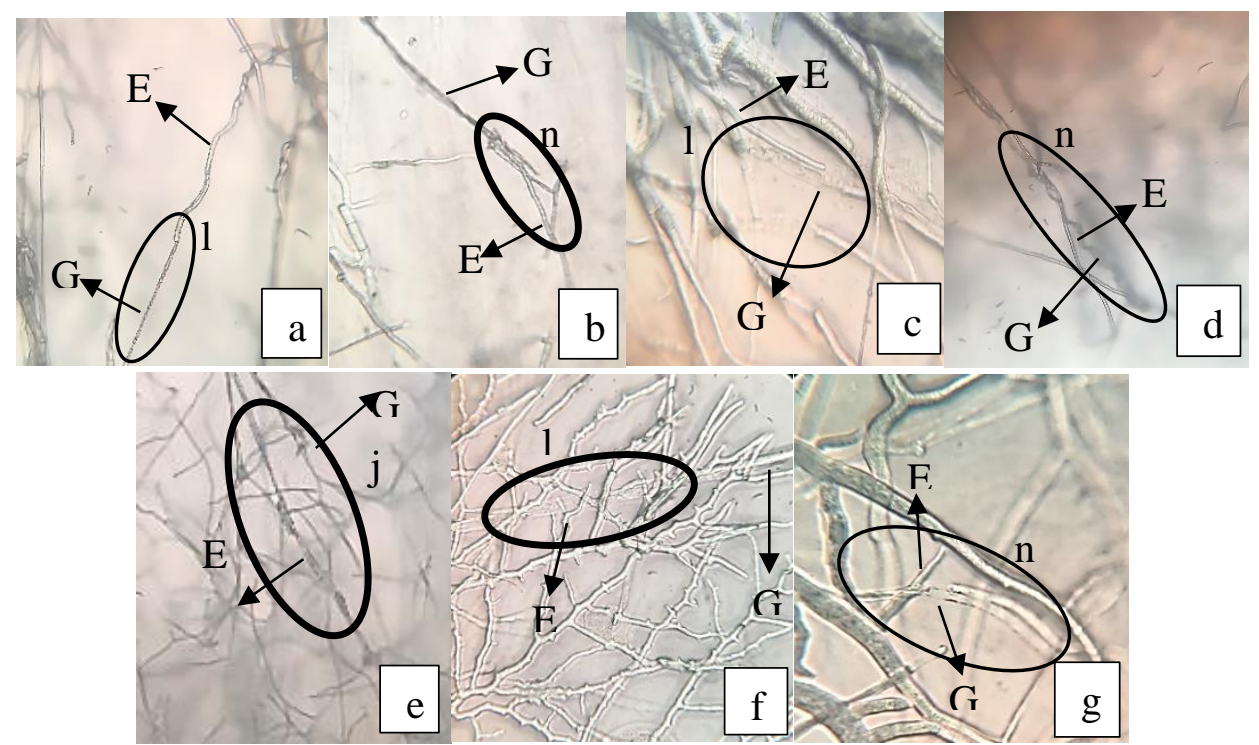

Gambar 2. Tipe interaksi tujuh isolat jamur endofit tanaman aren yang berdaya antagonis $>50 \%$ erhadap $G$. boninense. a) Isolat $\mathrm{E}_{2}$, b) Isolat $\mathrm{E}_{3}, \mathrm{c}$ ) Isolat $\mathrm{E}_{18}$, d) Isolat $\left.\mathrm{E}_{15}, \mathrm{e}\right)$ Isolat $\left.\mathrm{E}_{16}, \mathrm{f}\right)$ Isolat E17, g) Isolat $\mathrm{E}_{25}$. $\mathrm{G}=$ hifa jamur $\mathrm{G}$. boninense, $\mathrm{E}=$ hifa jamur endofit, $\mathrm{j}=$ penjeratan, $\mathrm{n}=$ penempelan, $\mathrm{l}=$ pelisisan

Interaksi antara isolat $\mathrm{E}_{3}, \mathrm{E}_{15}, \mathrm{E}_{25}$ dengan $G$. boninense pada menunjukkan adanya penempelan hifa jamur endofit pada hifa patogen (Gambar 2b, 2d dan 2g). Menurut Dolakatabadi et al. (2012) jamur endofit membentuk hifa runcing di sekitar hifa patogen sebelum penetrasi atau masuk secara langsung. Selain penempelan, hifa jamur endofit juga ada yang seperti menjerat hifa patogen misalnya pada isolat E16 (Gambar 8e). Penjeratan yang merupakan proses lanjutan dari pelilitan dan menyebabkan hifa patogen tidak berkembang. Kurnia dkk. (2014) juga menemukan bahwa hifa jamur antagonis dapat menjerat hifa jamur patogen dan menyebabkan hifa patogen pertumbuhannya terhenti. Alamsyah (2018) menyatakan pula bahwa tahap pelilitan dan penjeratan diduga memiliki aktivitas lanjutan berupa produksi enzim-enzim oleh jamur antagonis yang berperan dalam perusakan jamur patogen. Lebih jauh, Dwiastuti dkk. (2015) menyebutkan bahwa pembelitan hifa merupakan tahap awal proses antagonisme isolat Trichoderma pada hifa jamur patogen yang selanjutnya akan merupakan intervensi hifa jamur patogen sehingga antagonis dapat melakukan penetrasi pada hifa jamur patogen.

Hasil identifikasi dari ke tujuh isolat jamur endofit berdaya antagonistik $>50 \%$ termasuk ke dalam 5 genus yang berbeda-beda. Isolat E2, E16 dan E18 termasuk ke ke dalam genus yang sama yaitu genus Trichoderma (Gambar 3a, d dan f). Berdasarkan pendapat Watanabe (2002) Trichoderma sp. memiliki konidia berbentuk bulat, konidiofor tegak, bercabang dan tidak bersekat serta warna hifa yang hialin. Ketiga isolat tersebut termasuk ke dalam genus yang sama yaitu Trichoderma namun diduga dengan spesies yang berbeda. Isolat $\mathrm{E}_{3}$ memiliki konidia berbentuk bulat, konidiofor tegak, tidak bercabang dan tidak bersekat serta warna hifa yang hialin (Gambar 3b). Berdasarkan hasil pengamatan Isolat E3 termasuk ke dalam genus Aspergillus yang sesuai dengan buku "Pictorial Atlas of Soil and Seed Fungi" (Watanabe, 2002). 


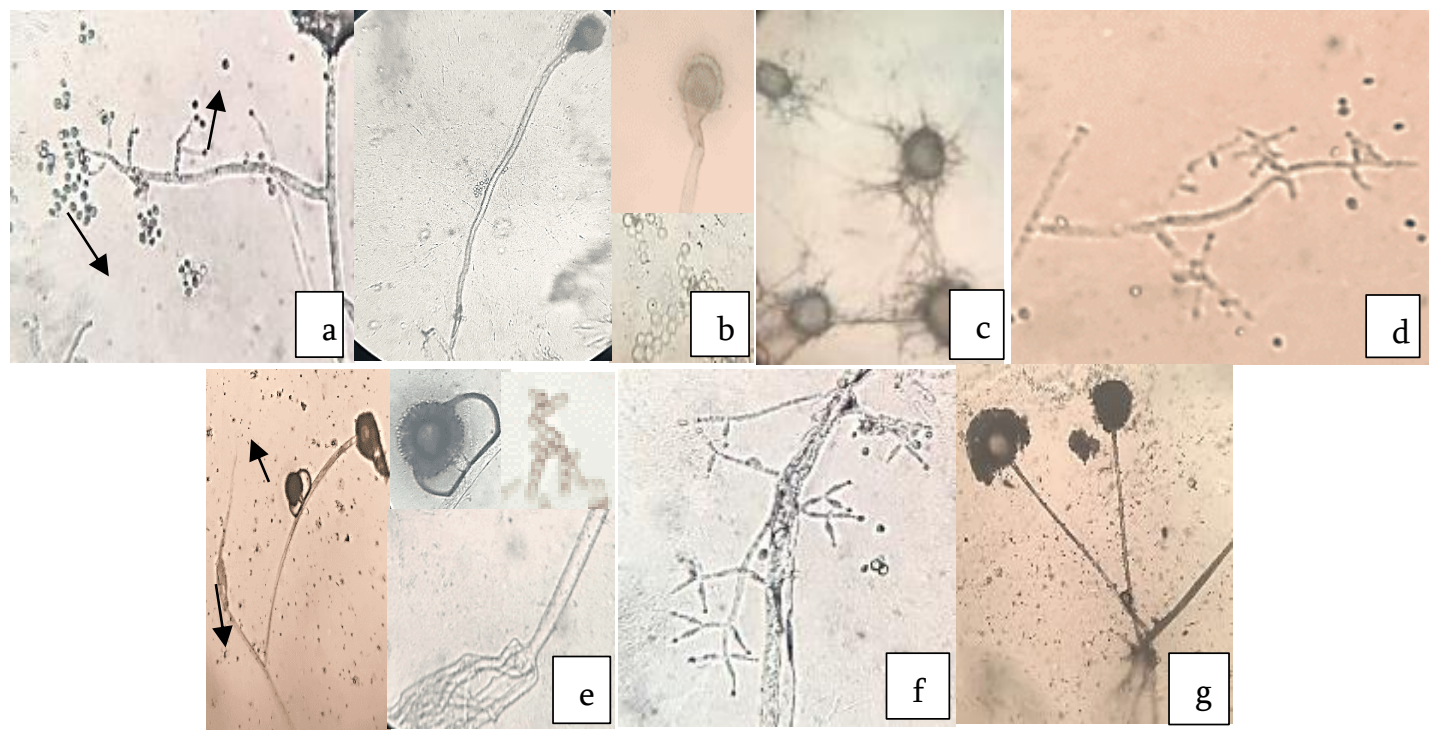

Gambar 3. Karakteristik mikroskopis isolat jamur endofit tanaman aren. A) Isolat E2, b) Isolat E3, c) Isolat E15, d) Isolat E16, e) Isolat E17, f) Isolat E18, g) Isolat E25

Karakteriskik mikroskopis isolat $\mathrm{E}_{15}$ yaitu memiliki konidia (papulospora) berbentuk bulat, konidiofor pendek, tidak bercabang dan tidak bersekat serta warna hifa yang hialin (Gambar 3c). Berdasarkan Watanabe (2002) karakteristik mikroskopis isolat $\mathrm{E}_{15}$ tersebut termasuk ke dalam genus Papulaspora. Isolat E17 memiliki karakteristik mikroskopis berupa sporangiofor tegak dan bercabang, vesikel yang terdapat merosporangia yang tersusun dari 1-8 sporangiospora berturut-turut, sporangiospora hialin dan berbentuk bulat, serta memiliki rizoid, termasuk ke dalam genus Syncephalastrum yang sesuai dengan identifikasi dari buku Watanabe (2002).

Karakteriskik mikroskopis isolat E25 memiliki sporangiofor hialin dan tidak bercabang, kolumela berbentuk elips, sporangium, sporangiospora hialin dan berbentuk bulat, serta memiliki rizoid (Gambar $2 \mathrm{~g})$. Berdasarkan hasil pengamatan E25 termasuk ke dalam genus Mucor. Menurut Watanabe (2002), Mucor sp. memiliki karakteristik mikroskopis yaitu sporangiofor yang tegak dengan cabang atau tidak, memiliki kolumela berbentuk bulat atau elips, memiliki sporangiospora yang hialin dan berbentuk bulat, serta terkadang memiliki rizoid.

\section{SIMPULAN}

1. Hasil isolasi dari tanaman aren diperoleh 25 isolat jamur endofit dengan tujuh isolat jamur endofit yang dapat menghambat pertumbuhan $G$. boninense sebesar 50,17\%-67,05\%.
2. Interaksi antara jamur endofit tanaman aren dengan $G$. boninense dapat berupa terjadinya lisis $\left(E_{2}, E_{17}, E_{18}\right)$, penempelan $\left(E_{3}, E_{15}, E_{25}\right)$ dan penjeratan $\left(\mathrm{E}_{16}\right)$ hifa patogen oleh hifa jamur endofit.

3. Jamur endofit yang berdaya antagonis tinggi terhadap G. boninense yaitu isolat $\mathrm{E}_{2}$, $\mathrm{E}_{16}$, dan $\mathrm{E}_{18}$ termasuk ke dalam genus Trichoderma, E3 termasuk ke dalam genus Aspergillus, E15 termasuk ke dalam genus Papulaspora, E17 termasuk ke dalam genus Syncephalastrum, dan E25 termasuk ke dalam genus Mucor.

\section{UCAPAN TERIMA KASIH}

Penulis ucapkan terima kasih kepada pihak Fakultas Pertanian Universitas Riau dan Laboratorium Penyakit Tumbuhan yang telah memberikan fasilitas untuk pelaksanaan penelitian ini.

\section{DAFTAR PUSTAKA}

Alviodinasyari, R, A Martina, dan W Lestari. 2015. Pengendalian Ganoderma boninense oleh Trichoderma sp. SBJ8 pada kecambah dan bibit kelapa sawit (Elaeis guineensis Jacq.) di tanah gambut. JOM FMIPA. 2(1): 99-107.

Amaria, W, E Taufiq, dan R Harni. 2013. Seleksi dan identifikasi jamur antagonis sebagai agens hayati jamur akar putih (Rigidoporus lignosus) pada tanaman karet. Buletin RISTRI. 4(1): 1-8. 
Barnett, HL, and BB Hunter. 1998. Genera of Imperfect Fungi. $4^{\text {th }}$ Ed. APS Press. Minnesota.

Dinas Perkebunan Provinsi Riau. 2014. Laporan tahun 2010. Pekanbaru.

Direktorat Jendral Perkebunan. 2021. Luas Areal Kelapa Sawit Menurut Provinsi di Indonesia, 2017-2021. Jakarta.

Dolakatabadi, HK, EM Golatpeh, N Mohammadi, M Rabiey, N Rohani, and Varma. 2012. Biocontrol potential of root endophytic fungi and Trichoderma spesies against fusarium wilt of lentil under in vitro and greenhouse condition. Journal Agr. Sci. Tec. 14: 407-420.

Dwiastuti, ME, MN Fajri, dan Yunimar. 2015. Potensi Trichoderma spp. sebagai agens pengendali Fusarium spp. penyebab penyakit layu pada tanaman stroberi (Fragaria $\mathrm{x}$ ananassa Dutch.). J. Hort. 25(4): 331-339.

Krishnamurthy, J, R Samiyappan, P Vidhyasekaran, S Nakkeeran, E Rajeswari, JAJ Raja, and P Balasubramanian. 1999. Efficacy of Trichoderma chitinases against Rhizoctonia solani, the rice sheath blight pathogen. J. Biosci. 24(2): 207-213.

Kurnia, TA, MI Pinem, dan S Oemri. 2014. Penggunaan jamur endofit untuk mengendalikan Fusarium oxysporum f.sp. capsici dan Alternaria solani secara in vitro. Jurnal Online Agroteknologi. 2(4): 1596-1606

Otten, W, DJ Bailey, dan CA Giligan. 2004. Empirical evidence of spatial thresholds to control invation of fungal parasites and saprotrophs. Jurnal New Phytologist. 163: 125-132.

Pelczar, MJ, and ECS Chan. 1988. Dasar-Dasar Mikrobiologi. UI Press. Jakarta.

Purwanti, S, dan RB Hastuti. 2009. Uji antagonisme jamur patogen Phytophthora infestan penyebab penyakit busuk daun dan umbi tanaman kentang dengan menggunakan Trichoderma spp. isolat lokal. Jurnal Bioma. 11(1): 24-32.

Sari, W, dan E Setiwanto. 2015. Potensi cendawan rizosfer pisang sebagai agen hayati terhadap cendawan Fusarium oxysporum f.sp. cubense penyebab penyakit layu pada pisang. Jurnal Agroscience. 1(2): 37-42.

Skidmore, AM. 1976. Interaction in relation to biological control of plant phatogen. In $\mathrm{Pp}$. 507-527. Microbiology of Aerical of Plant Surface (CH Dicjision and TF Preece, Eds.). Academic Press. New York.

Susanto, A. 2002. Kajian pengendalian hayati Ganoderma boninense penyebab penyakit busuk pangka batang kelapa sawit. [Disertasi]. Pascasarjana Institut Pertanian Bogor. Bogor.

Vinale, F, K Sivasithamparam, EL Ghisalberti, and M Lorito. 2008. Trichoderma plant pathogen interaction. Soil and Biohemistry. 40(1): 1-10.

Watanabe, T. 2002. Pictorial Atlas of Soil and Seed Fungi. CRC Press. Boca Raton.

Wilia, W, I Hayati, dan D Ristyadi. 2012. Eksplorasi cendawan endofit dari tanaman padi sebagai agens pemacu pertumbuhan tanaman. Bioplantae. 1(4): 73-79.

Wulandari, E, T Idiyanti, dan E Sinaga. 2012. Limbah molase: pemanfaatan sebagai sumber karbohidrat untuk perkembangbiakan mikroorganisme. J. Valensi. 2(5): 65-572.

Yusriani, M. 2019. Uji Potensi Antagonis Isolat Jamur Endofit Dari Tanaman Sagu (Metroxylon spp.) terhadap Ganoderma boninense Penyebab Penyakit Busuk Pangkal Batang Pada Tanaman Kelapa Sawit (Elaies guineensis Jacq.). [Skripsi]. Universitas Riau. Pekanbaru. 